
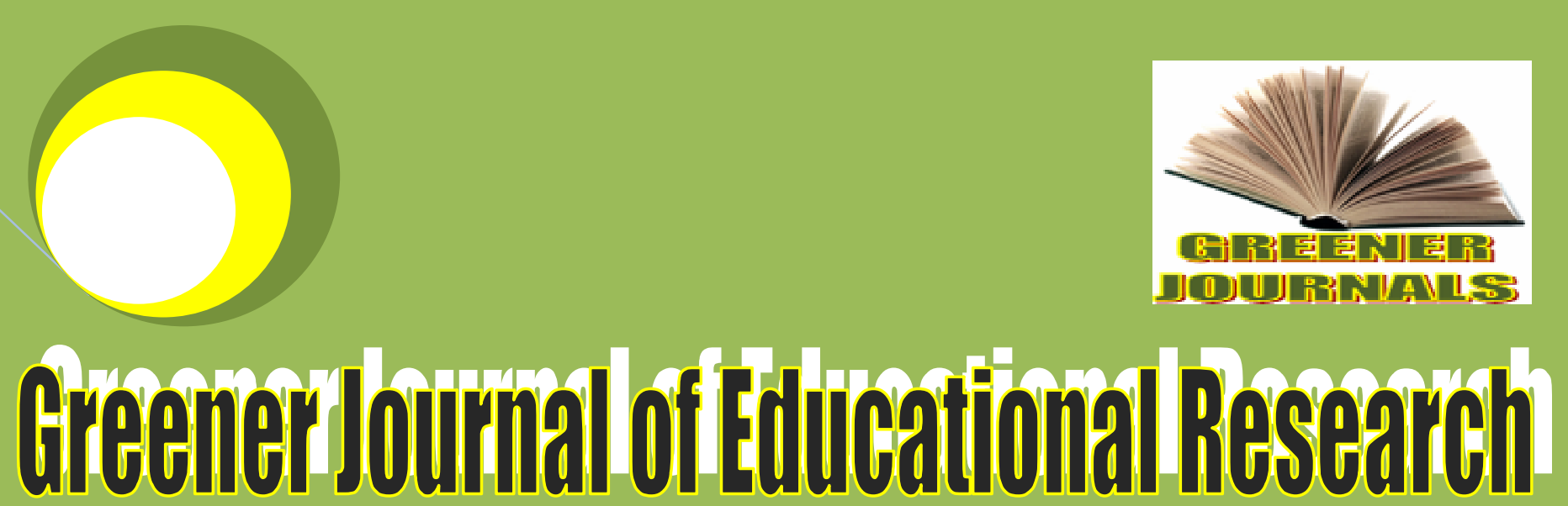

ISSN: 2276-7789 ICV: 6.05

Submitted: 28/03/2016

Accepted: 06/04/2016

Published: 30/04/2015

DOI: http://doi.org/10.15580/GJER.2016.2.032816070

Impact of Free

Secondary Education

Policy on Access to

Secondary School

Education in Kenya. A

Case Study of Mbita

and Suba Sub-Counties

By

Maurice Aoko Ndolo

Enose MW Simatwa

Theodore MO Ayodo 


\title{
Impact of Free Secondary Education Policy on Access to Secondary School Education in Kenya. A Case Study of Mbita and Suba Sub-Counties
}

\section{${ }^{1}$ Maurice Aoko Ndolo, ${ }^{* 1}$ Enose MW Simatwa and ${ }^{2}$ Theodore MO Ayodo}

\author{
${ }^{1}$ Department of Educational Management and Foundations, Maseno University. \\ ${ }^{2}$ Faculty of Education, Arts and Theology, Kabarak University. \\ *Corresponding Author's Email: simatwae @yahoo .com
}

\begin{abstract}
Free Secondary Education policy was introduced in Kenya in 2008 ostensibly to make secondary school education affordable so as to enhance access, transition and student academic performance. Studies in USA, USSR, Japan, Sub Saharan Africa and some parts of Kenya like Kangundo sub county have revealed that subsidized fees at all levels of education and particularly at primary and secondary school education levels enhance access, transition and academic performance. This seemed not to be the case in Mbita and Suba sub counties, where Gross Enrolment Rates were low at $4948(33 \%)$ and $3546(25 \%)$ respectively for the 2014 against national Gross Enrolment rate of $47.8 \%$. The transition rates from 2010 to 2014 were $39.4 \%, 41.2 \%, 40.4 \%, 54.5 \%, 59.2 \%$ for Mbita Sub county, 56.2\%, $54.4 \%, 61.1 \%$ and $59.2 \%$ for Suba Sub county which were lower than the national transition rates of $68.9 \%, 69.4 \%, 68.4 \%, 76.8 \%$ and $80.4 \%$ for the same period while academic performance mean scores in Kenya Certificate of Secondary Education for 2011 and 2014 were low at 5.0 and 5.1 respectively. The objective of this study was to determine the influence of free secondary education policy on access to secondary school education in Mbita and Suba Sub-counties. The study involved the cohorts of students from the year 2008 to 2014, that is, the 2008, 2009, 2010 and 2011 cohorts. Analysis of the impact of Free Secondary Education policy on access to secondary school education showed that free secondary education policy was inextricably connected with access to secondary school education. Also, it is noteworthy that the coefficient of Free secondary education funding in small secondary schools was statistically significant with a positive sign, which depicted that by one unit increase in Free Secondary Education funds, the increase in access was by 409.592 units, in medium secondary schools, the coefficient of Free Secondary Education funds was statistically significant with a positive sign which depicted that by one unit increase in Free Secondary Education funds, the increase in access was by 711.803 units and in large secondary schools, the coefficient of Free Secondary Education funds was statistically significant with a positive sign which depicted that by one unit increase in Free Secondary Education funds, the increase in access was by $\mathbf{3 7 0 0 . 1 6 7}$ units. It is clear that on average, one unit increase in Free Secondary Education funds increased access to secondary school education by 947.489 units in Mbita and Suba Sub counties, Kenya.
\end{abstract}

Key Words: Influence, Free Secondary Education Policy, Access, Mbita, SubaSub - Counties, Kenya.

\section{INTRODUCTION}

Free Secondary Education policy was introduced in Kenya in 2008 with an aim of making secondary education affordable (Ministry of Education, 2007). The social pillar in the Vision 2030 also singles out education as an important vehicle that will propel Kenya into becoming a middle-income economy. In addition, the Constitution, 2010 has provided for free and compulsory Basic Education as a human right to every Kenyan child (Ministry of Education, 2012).Free Secondary Education policy was expected to provide an equal opportunity to all secondary school going age entry to secondary education regardless of their social class, gender, and ethnic background, physical and mental disability (Ngeno, 2015). The objectives of Free Secondary Education were to enhance access to secondary education, improve quality, equity, relevance and gender parity in the provision of secondary school education (Ministry of Education, 2007). In order to achieve these objectives and execution of Free Secondary Education was done. However, there was inadequate evidence on the influence of Free Secondary Education policy on access, transition and student academic performance in Mbita and Suba sub-counties. As a result of increased financial 
support, it was expected that access and the number of students transiting form primary to secondary would improve with Free Secondary Education funding and was expected to provide adequate resources to students especially candidates and it was hoped that this would increase academic performance. Coombs (1968) defines quality of education as that education being offered that currently fits the real needs and values and prospectively of a given country. Therefore quality education is the degree of achievement in education as evidenced in national examinations, transition from one level to the next and access. The first cycle of students who benefited from Free Secondary Education policy graduated in 2011(Ngeno \& Simatwa, 2015).

Data from Homa-Bay County Education Office (2014) indicated that the Gross Enrolment Rate in Mbita and Suba Sub counties was 33\% and 25\% respectively for 2014 against national Gross Enrolment Rate of $47.8 \%$. The transition rate from 2010 to 2014 were $39.4 \%, 41.2 \%, 40.4 \%, 54.5 \%, 59.2 \%$ for Mbita sub-county while Suba was $56.2 \%, 54.4 \%, 61.1 \%$ and $59.2 \%$ which are lower than the national transition rates of $68.9,69.4,68.4,76.8 \%$ and $80.4 \%$ for the same period. Academic performance mean scores in Kenya Certificate of Secondary Education for 2011 and 2014 were low, 5.0 and 5.1 for Mbita and Suba respectively. This brought to the fore the question: What is the impact of Free Secondary Education policy on access, transition and students academic achievement. This is the problem that this study sought to solve.

Literature review showed that a number of studies had been carried out in this area. For instance, Gogo (2003) examined the impact of cost sharing strategy on access, equity and quality of secondary education in Kenya. The research design used was correlational. Stratified random sampling technique was used to get the sample of the study. The respondents included head teachers and 12 students selected from each of the 32 out of 46 schools (69.6\%) sampled in addition to the District Education Office Rachuonyo District. A total of 417 respondents were used. Questionnaire was used as the major instrument for data collection. In addition, documents from schools, District Education Offices and libraries were read for further information. Data analysis incorporated descriptive statistics, time trends and multiple linear regression methods. The independent variables were tested for significance at 0.05 level of confidence in a two tailed test. The study showed that enrolment in the district remained low because the parents had found it difficult to raise the required fees. However, after the introduction of free secondary education, the situation would be the same, hence the need to find out the current situation of access after the implementation of Free Secondary Education policy. Chabari (2010) carried out a study on the challenges of implementation of Free Secondary Education in public secondary schools in Kangundo District in Kenya. The findings of the study indicated that following the introduction of Free Secondary Education policy, the average number of students in schools increased steadily, thus leading to overcrowded classrooms. Further, the study reported that the funds released by the government were inadequate and were never released on time. However, the study by Chabari did not cover the entire county, hence could not find out if the same situation in Kangundo also applies to Mbita and Suba in Homa -Bay Counties. Ndolo, Simatwa and Ayodo (2011) examined the effects of school-based investments on access and financing of secondary education in Homa-Bay District, Kenya. Cross sectional survey design was used. The study population consisted of 297 students, 33 principals and 1 District Education Officer. Questionnaire was used to collect data which was analyzed using descriptive statistics, frequencies and cross tabulation. The study established that profits from Income Generating Activities lowered the cost of education in Homa-Bay District and subsequently increased access. This necessitated a study to find out if access increased after lowering the parents' Free SecondaryEducation policy which Ndolo's (2011) assess would have improved.

On transition, Ngware, Oketch, Ezeh and Mudege (2009) examined whether households characteristics matter in schooling decisions in urban Kenya. The study established that the whole transition rate across all the study sites was about $75 \%$. Both sexes combined, the lowest rate of transition was observed in Mombasa (66\%) while highest in Kisumu (83\%). The study further found out that there was a strong association between the household wealth index and probability of the transition. It was therefore necessary to establish whether the same scenario affects Mbita and Suba Sub-counties. The two Sub-counties are located in Homa Bay County whose neighbor Kisumu had the highest transition rate. Further, many parts of Homa-Bay, County especially Mbita and Suba experience high poverty levels, low income and HIV and AIDs pandemic which might affect transition in those regions (Ndolo, 2011). Consequently, Free Secondary Education policy was introduced to enhance the transition of pupils from primary schools to secondary schools, improve on the quality of secondary education and reduce wastage.

Ngeno and Simatwa (2015) examined the influence of Free Secondary Education policy on dropout rates in Kenya: A case study of Kericho County. The study population was 4,457 principals, Sub County Quality Assurance and Standard Officers, Directors of Studies and form IV students of 2011. Questionnaire, interview schedules, Focus group discussion guide and document analysis guide were used to collect data. Quantitative data was analyzed using cohort analysis, descriptive and inferential statistics. Qualitative data was transcribed and analyzed in emergent themes and sub themes. The study showed that form to form transition of the three cohorts (form I, II, III and IV from 2004 to 2007) were as follows; 9103; 9333; 9217 and 9281, the 2005 cohort transited as follows: 9434 ; 
9434; 9434; 9329 and 9237 and the 2006 cohort transited as follows: 10516 and 10637 . The fluctuations could be attributed to repetitions and dropout because on the whole, a general decline could be observed as students transited from form one to form four for the 2004 cohort. This trend was of concern because with the introduction of Free Secondary Education policy, the participation rates were expected to increase and be sustained (Ngeno \& Simatwa, 2015). It was therefore plausible to examine if the same trend applied to other areas in Kenya apart from Kericho, hence the need to examine Mbita and Suba Sub-counties in order to establish whether the objective of Free Secondary Education policy to enhance transition of pupils from primary to secondary had been achieved. Furthermore, Ngeno and Simatwa (2015) examined the form to form transition rates contrary to the objectives of the Ministry of Education of transition from primary to secondary. Subsequently, this study assessed whether the objective of Free Secondary Education policy to enhance the quality of secondary education had been achieved.

Research Objective: To determine the Influence of Free Secondary School Education Policy on Access to Secondary Education in Mbita and Suba sub -counties, Kenya.

\section{SYNTHESIS OF LITERATURE ON ACCESS TO SECONDARY SCHOOL EDUCATION}

The wide gap in secondary enrolment rates between Sub-Saharan Africa and the rest of the world is raising concerns (Oketch, 2010). In the 20th Century, both the US and the Soviet education policies led to secondary school education models aimed at the creation of massive systems that emphasize open access and universal coverage (Karugu, 2006). After 1945, what were later called comprehensive secondary schools began to spread from northern to southern Europe. Extension of compulsory education had entirely changed the concept as well as the duration of basic education to the point that the basic education usually included lower secondary schooling. Rising average schooling was as important as study objective and as a measure of the success of education reforms (Chabari, 2010). Many other countries have embraced the goal of extending and expanding the idea of basic education to include much of what used to be restricted access, elitist secondary education. In Japan, the government fiscal policy provided for free education to secondary school level. Those of school going age had no option other than attend school to acquire education that is fully funded by the government (Nyaegah, 2005). In the USA, the federal government supports public education. The government is empowered by the constitution welfare clause article 1 section 8 to levy and collect revenues for the support of education. The situation in Kenya is not different from that of Japan and USA. In Canada, school fees are an integral part of an education system. Parents are to contribute to their children's education through payment of fees (Nyaegah, 2005). The government recognizes that some parents are sincerely not in a position to pay, so the government makes provision to ensure that a child is not denied access to education because of an honest inability to pay fees. The department of education in Canada works with school boards, parents, teachers and other partners to ensure that policies governing school fees are implemented consistently in all provinces.

The International community pledged to meet the targets of Education for All and the Millennium Development Goals by 2015 and as a result, many governments particularly in the Sub- Saharan Africa are considering abolishing school fees for secondary school education (Ohba, 2009). This is particularly due to domestic and international demand to achieve Education for All and sustainable Development Goals. Fees charged in secondary schools are indeed the major obstacles for some children to access secondary school education, resulting in low transition rates from primary to secondary. Thus many governments in SSA have planned to abolish secondary education school fees (Ohba, 2009). This is against the back drop that many governments in SSA are under severe budget constraints, especially after the global recession. Thus while the governments are intending to extend free education, they often allow public schools to levy fees for limited items such as sports fees, school meals, uniforms and photocopying papers etc. Even though officially most school fees are not sanctioned by the government, the fees are often used to make up for lost revenue due to delay in government subsidies. While asking many questions about access, evidence indicates that secondary enrolment rates in SSA continue to be the lowest in the world (Ohba, 2009). Approximately 104 million secondary school -age children in the region, only one in four (25\%) were enrolled in secondary in 2006 (UNESCO, 2008). Of these, there were 83 girls only for every 100 boys. This figure is a critical challenge as compared to other regions. One of the challenges of gaining access to secondary education in Sub Saharan is user fees which are mentioned as a barrier in terms of affordability (Ohba, 2009). In SSA, user fees are identified as a barrier to education (Veriava, 2002). The school budgets are funded by allocations from state revenue, school fees are required to supplement these budgets so that schools are able to run smoothly. The Sub Sahara Africa School act provides that a majority of parents at a public school may determine whether or not school fees are charged and the amount paid. There was however exemption from paying school fees for parents who could afford to meet the cost. Exemption is extended to parents whose income is less than 30 times, but more than 10 times the amount of fees (Veriava, 2002). In Kenya the government has a uniform allocation criterion for 
secondary tuition, meaning that education is accessible to every qualifying student graduating from primary school. Even in countries where public education has traditionally been free, private contributions to the financing of government schools are increasingly important. Lewin (2008) observed that in public schools in Uganda, Tanzania and Zambia, more than half of total costs per student are financed through fees and other parental contributions. In Kenya, the Board of Governors hire additional teachers paid from the income to fill teaching positions for which no government teachers have been assigned and virtually all physical facilities for the government secondary schools have been funded by parents (Republic of Kenya, 2005). Zambia established in 1996 education production units which enroll students who fail to find regular places in fee- paying afternoon sessions run by teachers who participate on voluntary basis to supplement their income in school premises. In Rwanda $80 \%$ of students are enrolled in private schools, almost $40 \%$ of which receive no public subsidy have to rely on fee income (Verspoor, 2008). The initiative of Free Secondary Education was to ensure that every child could access secondary education by reducing the financial burden on parents. Unlike countries mentioned, that is, Zambia and Rwanda ,the situation in Kenya is quite different because education should be free and compulsory up to secondary level according Basic Education Act, 2012 (Republic of Kenya, 2013). Lack of access was said to be due to inadequate number of schools in both rural, urban and especially Arid and Semi Arid Land areas. Within the school also, the places available are not adequate to match demand. These inadequacies are more pressing at the secondary school level (Republic of Kenya, 1999). Koech commission recommended a mechanism for the provision of Basic Education for all and the strengthening of co-ordination in mobilizing and encouraging education providers. At the same time, necessary changes should be instituted for making education affordable for the average Kenyan parent. The government to take necessary steps to plan and implement strategies for increasing access at the secondary school level to accommodate all primary school learners (Republic of Kenya, 1999). Gogo (2003) carried out a study in secondary schools in Rachuonyo District and concluded that enrolment in the district remained low because parents had found it difficult to raise the required fees with ease making it difficult for the poor and the needy to afford secondary education. However, this study was carried out before the implementation of Free Secondary Education policy in 2008 thus the scenario today is different.

The commission of enquiry into the education system in Kenya pointed out that as Kenya moved towards the $21^{\text {st }}$ Century, the greatest challenge facing the nation is that of ensuring access to Basic Education For All, achieving equity by eliminating all existing disparities with particular reference to education of girls, women, children with special needs, children in disadvantaged regions such as Arid and Semi Arid Lands and education of Children in especially difficult circumstances both in urban and rural areas (Republic of Kenya, 1999). This finding calls for a different approach to the provision of, delivery, management and financing of education to ensure improved access, equity and quality within the context of newly defined goals and targets. Further, the convention of rights of children of which Kenya is a party provides the basics for all inclusive education system where no child is excluded or marginalized in special programs. Therefore, the obligation to ensure all children's rights to education lies with the government of Kenya. However, the research will find out whether with the introduction of Free Secondary Education policy, access to secondary education has improved. Saitoti (2004) reported that education takes one of the largest shares of resources in public expenditures. In 2002/2003 Kenya's financial year, education accounted for $20 \%$ share of public expenditure. It was only second to Defence and Public administration $29 \%$ while debt service $17 \%$, Economic services $13 \%$ and Health $6 \%$. The minister further highlighted that in spite of this high expenditure, the following factors militates against access to education; About $57 \%$ of the population live in poverty, HIV and AIDS prevalence is $9.4 \%$, malaria is costly and reduces productivity. There is limited access to development, that is, good health, education, clean water and poor infrastructure.

Despite various initiatives by the government, that is, providing support to poor and disadvantaged students through secondary school bursaries; providing targeted support for the development of infrastructure in areas where parents are not able to provide such support, working in partnership with parents, communities, private sector and other stakeholders in providing secondary education, the secondary sub-sector continues to face challenges particularly the low participation rates (Republic of Kenya, 2005). A report of the Task Force on Affordable Secondary Education (Ministry of Education, 2012) observed that despite the growth in number of schools and enrolment, the increase in the supply of secondary school places has been insufficient to improve participation rates. In 2006, gross and net enrolment rates were recorded to be only $32 \%$ and $23 \%$ respectively having increased from the academic year 2002 level of $27 \%$ and $17 \%$ respectively. Some of the challenges facing secondary education includes; high dropout rates (21\% do not complete school), poor infrastructure, limited spaces, cost of education, student/ teacher ratio is high, inadequate textbooks and other compliments, regional and gender disparities, limited opportunities for the handicapped population. Further, based on 1999 census data, a total of 2.8 million boys and girls aged 14 and 17 years who should have been in school were not enrolled; it was thought that policy measures were necessary ingredients to address the poor access to secondary education as a way of supporting the country's overall development goals (Republic of Kenya, 2010). There is a need to get more information on whether Free Secondary Education policy influences access, hence the purpose of the study. 
Chabari (2010) carried out a study on the challenges of implementation of Free Secondary Education in public secondary schools in Kangundo district in Kenya. He applauded the initiative of starting Free Day Secondary School Education as a worthy cause because it enhanced access to education despite many challenges. The introduction of Free Day Secondary School Education in 2008 had an immediate impact on enrolment at secondary school level. The number of secondary schools increased from a total 6566 secondary schools in 2008 to 7308 in 2009. Enrolment grew from 1.18 million students in 2007 (639, 393 boys and 540, 874 girls) to 1328, 964 (735,680 boys and 593, 284 girls) in 2008 and further 1,500, 015 (804, 119 boys and 695, 896 girls) in 2009 (Ministry of Education, 2012). However, it was disturbing to note that despite the introduction of Free Day Secondary Education, some areas were doing quite poorly in enrolment. A newspaper, Education News, reported that enrolment of pupils in public primary schools in Central province in Kenya was declining at an alarming rate. Some schools with well established infrastructure had been left with empty classrooms and the number of pupils declined. In Maragua primary school, the number reduced from 1500 to 542 within a decade (Njoroge, 2011). The scenario calls for an evaluation of Free Day Secondary Education programmes to assess their impact on access. Nyaegah (2011) carried out a study on education and millennium development goal challenges facing the management of Free Primary Education in Nyamira County in Kenya. He underscored the fact that the government policy of FPE would substantially contribute to meeting Millennium Development Goals goal of universal access to primary education by the year 2015. Equally, it was the aim of the government to improve access to secondary level with the introduction of Free Day Secondary School Education. However, Nyaegah reported that the education sector was faced with many challenges including finance, and lack of adequate teachers, insufficient learning facilities which hinder the government from achieving this goal, hence the need to evaluate the impact of Free Day Secondary Education on access, equity and quality of education in Kenya.

The task force on the re-alignment of the education sector to the constitution of Kenya expresses a similar fact. That is, access, equity, quality and relevance of education are fundamental characteristics that define and drive systems of education and training. They reported that governments worldwide pay special attention to the four characteristics (Ministry of Education, 2012). There are however, many challenges which threaten the sustainability of a robust education regime in Kenya. The key challenges include low enrolment and retention rates, constricted access and equity at the higher levels, establishment and maintenance of quality and relevance, and myriad inefficiencies in managing the limited resources allocated to the education sector (Republic of Kenya, 2005). However, our main concerns in the study are access and quality at secondary school level. As cited elsewhere, this level is important in any Education system because students are prepared for various fields of work at this level. Hence for sound planning, the government should pay keen attention on access and quality at secondary school level. Economic survey (Republic of Kenya, 2012b) reported that the continued implementation of Free Tuition Secondary Education policy together with other government initiatives such as Constituency Development Fund have increased access to secondary education. Enrolment in secondary schools by class and sex from 2007 to 2011 rose by $5.9 \%$ from 1.7 million in 2010 to 1.8 million in 2011. Girls enrolment increased by $4.1 \%$ from 767,847 in 2010 to 819,014 in 2011 while boys enrolment rose by 3.7\% to 948,706 in 2011 (Republic of Kenya, 2012 b). However, a number of challenges reported still indicate that gender parity still exists and a number of challenges are undermining government policy on free secondary education.

Consortium for Research on Education Access, Transition and Equity (CREATE) carried out a study in rural Kenya to establish whether Free Secondary Education has enabled the poor to gain access to secondary education. The report indicated that free secondary education cannot solve the problem of access. Some parents interviewed said that while lowering school fees has enabled some to take their children to school, this does not mean all children from poor households are assisted to gain access to secondary education. Household income for many families has not changed while most prices of food and other commodities have soared thus reducing their ability to pay fees even in a day school (Ohba, 2009). It was expected that the county records $90 \%$ access for both primary and secondary. However, this is not the case. Poverty, low income and HIV/and AIDS scourge has orphaned many children, leaving them destitute and unable to meet their housing, educational, health, food and clothing needs (Ndolo, Simatwa \& Ayodo, 2011). The reviewed studies did not address access in Mbita and Suba sub-counties, the gap in knowledge this study sought to fill.

\section{CONCEPTUAL FRAMEWORK}

This study was based on Psacharopoulous and Woodhall (1985) concept of investment choices. The concept was relevant because the government made a choice to invest in education in order to improve access. The conceptual framework (Figure 1) postulates that provision of Free Secondary Education funds to secondary schools directly affects access. 


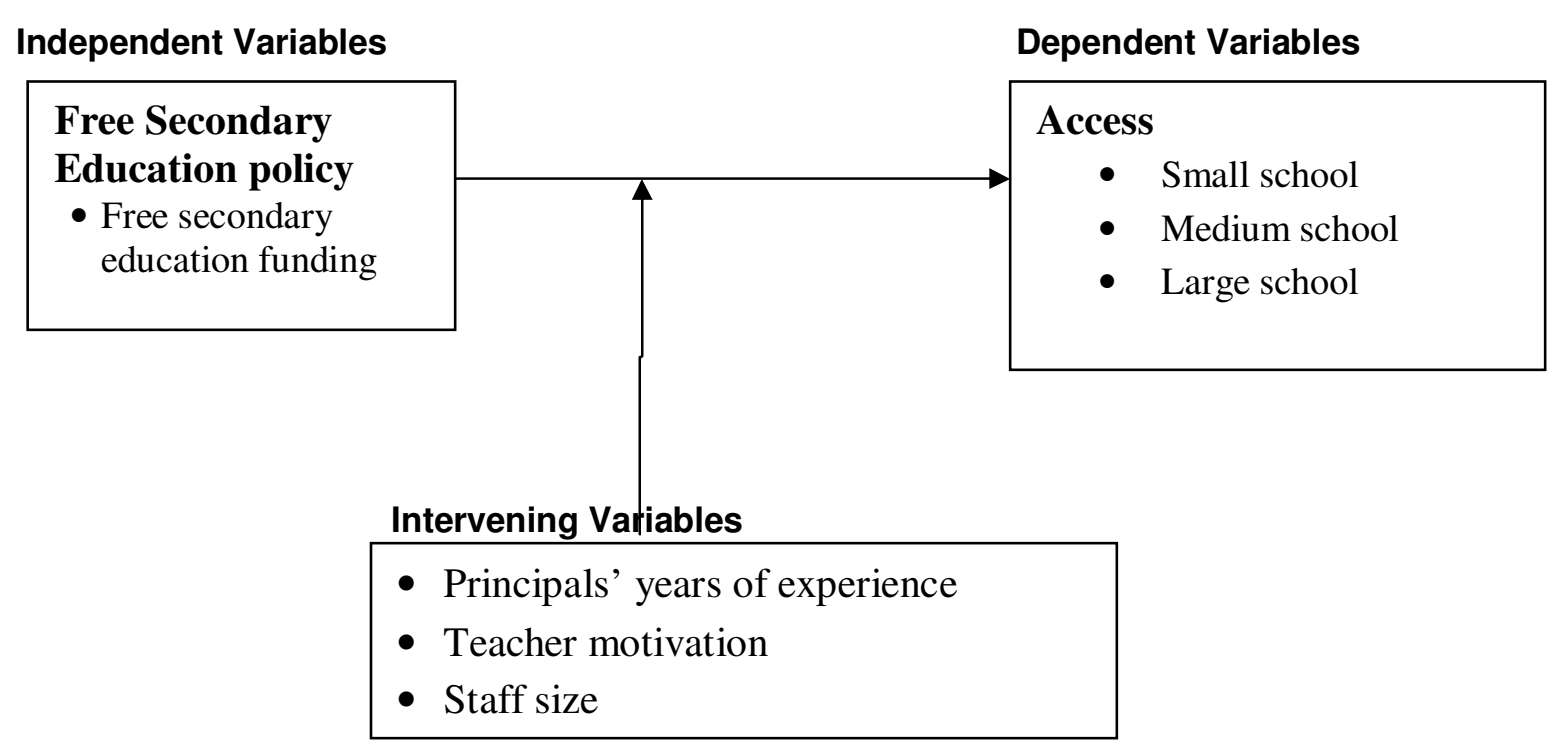

Figure 1: Conceptual Framework showing the Influence of Free Secondary Education Policy on Access to Secondary School Education

Availability of Free Secondary Education funds was expected to increase demand for secondary school education with more students expected to enroll in schools, hence increase in access. As a result of increased access and financial support, it was expected that there would be increase in students' transition from primary to secondary schools. However, academic performance may be confounded by experience of the principals, number and motivation of teachers in schools and student home environment such as social economic status of the households and distance to schools. To measure effect of Free Secondary Education on access, intervening variables; principals' years of experience and number of teachers were accounted for in the regression analysis as confounding factors by including them as independent variables.

\section{RESEARCH METHODOLOGY}

The study adopted ex-post facto and correlational research designs. The study population consisted of 37 principals, 2775 students, 1 Sub-county Schools Auditor and 2 Sub-county Quality Assurance and Standards Officers. The study sample consisted of 34 principals, 1 Sub-county Schools Auditor, 2 Sub-county Quality Assurance and Standards Officers who were selected using selected sampling technique and 337 form IV students of 2014 who were selected using simple random sampling technique. Questionnaire, Interview Schedule, Focus Group Discussion and Document Analysis Guide was used to collect data. Face and content validity of the questionnaire was established by supervisors by including their input. Construct validity was determined by correlation. Reliability of instruments was established through a pilot study in 3 schools using test-retest method whereby the principals questionnaire had a coefficient of 0.79 which was greater than the set $\mathrm{P}$-value of 0.05 and therefore was reliable.

\section{RESULTS}

\section{Demographic Characteristics of Principals}

The demographic data of principals were as shown in Table 1. 
Table 1: Characteristics of Principals

\begin{tabular}{lcc}
\hline Demographic Characteristics & Frequency & Percentage \\
\hline Gender of Principals & 26 & 76.5 \\
Male & 8 & 23.5 \\
Female & $\mathbf{3 4}$ & $\mathbf{1 0 0 . 0}$ \\
$\quad$ Total & 2 & \\
Highest education level & 20 & 5.9 \\
$\quad$ Diploma & 12 & 58.8 \\
Graduate & $\mathbf{3 4}$ & 35.3 \\
Masters & & $\mathbf{1 0 0 . 0}$ \\
Total & 13 & \\
Year of experience & 12 & 38.2 \\
1-5 years & 9 & 35.3 \\
6-10 & $\mathbf{3 4}$ & 26.5 \\
11 and above & & $\mathbf{1 0 0 . 0}$ \\
Total &
\end{tabular}

Out of 34 principals who participated in the study, $26(76.5 \%)$ were males while the rest $8(23.5 \%)$ were females. Both male and female respondents were represented. Majority of the principals 20 (58.8\%) were graduates, followed by masters graduates $12(35.3 \%)$ and only $2(5.9 \%)$ were diploma holders. This is a reflection of a generally high level of education among principals. Majority of the principals $38.2 \%(n=13)$ had $1-5$ years of experience while $12(35.3 \%)$ and the rest $9(26.5 \%)$ had more than 10 years experience. This means that principals' responses were credible as they were experienced, qualified and gender wise inclusive.

\section{School Data}

The school data was as shown in Table 2.

Table 2: School Data

\begin{tabular}{lccc}
\hline School Size & Population & $\begin{array}{c}\text { Number of } \\
\text { Schools }\end{array}$ & Percentage \\
\hline Small & $128-933$ & 17 & 50.0 \\
Medium & $1,115-1,697$ & 12 & 35.3 \\
Large & $2,085-5,650$ & 5 & 14.7 \\
Total & & $\mathbf{3 4}$ & $\mathbf{1 0 0 . 0}$ \\
\hline
\end{tabular}

A total of 34 public secondary schools participated in the study of which 15 were from Suba sub-county and 19 were from Mbita sub-county. The schools were classified as small size, medium and large size based on the number of enrolments from 2008 to 2014. Small schools were schools with between 128-933 students; medium schools had between 1115-1697 sand large schools had 2085 to 5650 students. From table 4.3, it can be observed that out of 34 schools, $17(50 \%)$ were classified as small size, $12(35.3 \%)$ were medium sized and $5(14.7 \%)$ were classified as large size.

Research Objective: The research objective was to determine the influence of Free Secondary Education policy on access to secondary school education.

To address this objective, the null hypothesis: There is no statistically significant relationship between Free Secondary Education policy and access to secondary education in Mbita and Suba sub-counties was generated. To respond to this hypothesis, data on enrolment and Free Secondary Education funding were computed, correlated and regression analysis done. The results were as shown in Tables 3 and 5 to 20. 
Table 3: Descriptive statistics for Free Secondary Education funds and Enrolment 2008 to 2014

\begin{tabular}{|c|c|c|c|c|c|c|c|c|}
\hline $\mathbf{S} / \mathbf{N}$ & $\begin{array}{l}\text { Small } \\
\text { Schools } \\
\text { Free Secondary } \\
\text { Education } \\
\text { funding in } \\
\text { Kenya shillings }\end{array}$ & $\begin{array}{c}\text { Small } \\
\text { school } \\
\text { Enrolment }\end{array}$ & $\mathbf{S} / \mathbf{N}$ & $\begin{array}{l}\text { Medium } \\
\text { Schools } \\
\text { Free } \\
\text { Secondary } \\
\text { Education } \\
\text { funding in } \\
\text { Kenya } \\
\text { shillings } \\
\end{array}$ & $\begin{array}{c}\text { Medium } \\
\text { school } \\
\text { Enrolment }\end{array}$ & $\mathbf{S} / \mathbf{N}$ & $\begin{array}{c}\text { Large } \\
\text { School } \\
\text { Free } \\
\text { Secondary } \\
\text { Education } \\
\text { funding in } \\
\text { Kenya } \\
\text { shillings } \\
\end{array}$ & $\begin{array}{c}\text { Large } \\
\text { Schools } \\
\text { Enrolment }\end{array}$ \\
\hline \multicolumn{9}{|c|}{ 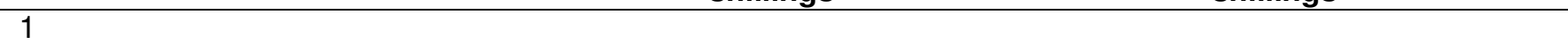 } \\
\hline & $2,309,625$ & 316 & 1 & $11,240,175$ & 1,220 & 1 & $21,145,900$ & 2,261 \\
\hline 2 & $4,157,325$ & 438 & 2 & $14,268,350$ & 1,461 & 2 & $22,736,975$ & 2,362 \\
\hline 3 & $6,559,335$ & 717 & 3 & $14,217,025$ & 1,412 & 3 & $27,150,925$ & 2,903 \\
\hline 4 & $8,427,565$ & 910 & 4 & $11,014,345$ & 1,115 & 4 & $53,993,900$ & 5,650 \\
\hline 5 & $8,509,685$ & 915 & 5 & $11,332,560$ & 1,171 & 5 & $21,032,985$ & 2,085 \\
\hline 6 & $3,366,920$ & 382 & 6 & $11,270,970$ & 1,170 & & & \\
\hline 7 & $1,806,640$ & 202 & 7 & $13,447,150$ & 1,427 & & & \\
\hline 8 & $5,840,785$ & 625 & 8 & $11,270,970$ & 1,137 & & & \\
\hline 9 & $4,054,675$ & 412 & 9 & $11,732,895$ & 1,246 & & & \\
\hline 10 & $3,182,150$ & 348 & 10 & $14,699,480$ & 1,697 & & & \\
\hline 11 & $8,509,685$ & 933 & 11 & $13,149,465$ & 1,355 & & & \\
\hline 12 & $3,233,475$ & 421 & 12 & $14,011,725$ & 1,647 & & & \\
\hline 13 & $5,399,390$ & 572 & & & & & & \\
\hline 14 & $1,847,700$ & 249 & & & & & & \\
\hline 15 & $5,748,400$ & 737 & & & & & & \\
\hline 16 & $1,324,185$ & 147 & & & & & & \\
\hline \multirow[t]{2}{*}{17} & $1,231,800$ & 128 & & & & & & \\
\hline & $75,509,340$ & 8,452 & & $151,655,110$ & 16,058 & & $146,060,685$ & 15,261 \\
\hline
\end{tabular}

The 34 schools were classified into three categories namely; small $(n=17)$, medium $(n=12)$ and large schools $(n=5)$ based on amount of Free Secondary Education funds received based on total enrolment. Small schools received below Kshs 10 Million, medium sized schools received (Kshs 10-20 million) and large schools received at least Kshs. 20 million as shown. Overall, the Free Secondary Education funds received by the small schools were Kshs.373, 225,135. Small secondary schools received Kshs. 75,509,340; medium secondary schools received Kshs151, 655,110 while the large secondary schools received Kshs.146, 060, 685.

Pearson's Correlation coefficients $(r)$ were therefore interpreted to determine the contribution and the influence of Free Secondary Education funds on access using Pearson's $r$. Pearson's $r$ was used to determine the direction and strength of the relationship. Elifson, Runyon and Haber (1990); Leedy and Ormrod (2005) interpretation guidelines were used as shown in Table 4.

Table 4: Interpretation of Pearson's Correlation Coefficients ( $r$ )

\begin{tabular}{ccl}
\hline Negative (-) & Positive (+) & Strength of the relationship \\
\hline $0.01-0.30$ & $0.01-0.30$ & Weak/low/small \\
$0.40-0.60$ & $0.40-0.60$ & Moderate/ medium \\
$0.70-0.99$ & $0.70-0.99$ & Strong/high \\
1.00 & 1.00 & Perfect relationship \\
0.00 & 0.00 & No relationship \\
\hline
\end{tabular}

Source: Adapted from Elifson, Runyon and Haber (1990); Leedy and Ormrod (2005) 


\section{Relationship between Free Secondary Education policy and Access to Secondary School Education}

Pearson's $r$ was used to establish the relationship between Free Secondary Education policy and access to secondary school education. The results were as shown in Table 5.

Table 5: Relationship between Free Secondary Education policy and Access to Secondary School Education

Access

Free Secondary

Education policy

\section{Pearson Correlation \\ Sig. (2-tailed)}

$\mathrm{N}$
.865

.000

34

From Table 5 it can be observed that there was a positive and strong relationship between Free Secondary Education policy and access. The relationship was significant as signified by the calculated $p$-value of .000 which was less than the set $p$-value of 0.05 . The null hypothesis was therefore rejected. This means that an increase in Free Secondary Education funds would increase students' enrolment.

To estimate the impact of Free Secondary Education funds, coefficient of determination was computed. The results were as shown in Table 6.

Table 6: Regression analysis of the impact of Free Secondary Education funds on Access

\begin{tabular}{llccc}
\hline Model & $\mathbf{R}$ & $\begin{array}{c}\mathbf{R} \\
\text { Square }\end{array}$ & $\begin{array}{c}\text { Adjusted } \\
\text { R Square }\end{array}$ & $\begin{array}{c}\text { Std. Error of the } \\
\text { Estimate }\end{array}$ \\
\hline 1 & $.865^{\mathrm{a}}$ & .748 & .741 & 543.926 \\
\hline \multicolumn{4}{l}{ Predictors: (Constant), Free Secondary Education policy }
\end{tabular}

From Table 6, it can be noted that the impact of the Free Secondary Education accounted for $74.8 \%$ of the variation on access as signified by the coefficient of 0.748 . The other $15.2 \%$ could be explained by other factors.

To determine whether Free Secondary Education was a significant predictor of access, ANOVA was computed. The results were as shown in Table 7.

Table 7: Analysis of Variance of the impact of Free Secondary Education policy on Access to secondary school education

\begin{tabular}{llrcccc}
\hline Model & & $\begin{array}{c}\text { Sum of } \\
\text { Squares }\end{array}$ & df & Mean Square & F & Sig. \\
& & & & & \\
\hline & Regression & $28,164,500.560$ & 1 & $28,164,500.560$ & 95.197 & $.000^{\circ}$ \\
& Residual & $9,467,364.176$ & 32 & $295,855.130$ & & \\
& Total & $37,631,864.735$ & 33 & & & \\
\hline
\end{tabular}

Predictors: (Constant), Free Secondary Education policy

From Table 7, it can be observed that Free Secondary Education policy was a significant predictor of access as the calculated p-value was $.000<0.05$. This means that Free Secondary Education funds can be relied on as a predictor of access to secondary school education.

To determine the actual impact linear regression analysis was done. The results were as shown in Table 8 
Table 8: Linear Regression Analysis of the impact of Free Secondary Education policy on access to secondary school education

\begin{tabular}{|c|c|c|c|c|c|c|}
\hline \multirow[t]{2}{*}{ Model } & & \multicolumn{2}{|c|}{$\begin{array}{l}\text { Unstandardized } \\
\text { Coefficients }\end{array}$} & \multirow{2}{*}{$\begin{array}{c}\text { Standardized } \\
\text { Coefficients } \\
\text { Beta }\end{array}$} & \multirow[t]{2}{*}{$t$} & \multirow[t]{2}{*}{ Sig. } \\
\hline & & B & Std. Error & & & \\
\hline & (Constant) & $1,222.168$ & 93.282 & & 13.102 & .000 \\
\hline 1 & $\begin{array}{l}\text { Free Secondary } \\
\text { Education policy }\end{array}$ & 947.489 & 97.110 & .865 & 9.757 & .000 \\
\hline
\end{tabular}

a. Dependent Variable: Access. Regression equation: $Y=a+b x$

From Table 8, it can be revealed that one unit increase in Free Secondary Education funds can lead to increase in access to secondary school education by 947.489 units as indicated by the coefficient 947.489 . The regression equation is $Y=1,222.168+947.489 X$. This means that Free Secondary Education policy has a high impact on access to secondary school education.

The study rigorously interrogated the influence of free secondary policy on access by categorizing schools into small, medium and large. The study sought to establish the relationship between Free Secondary Education policy and access according to school size. This was necessary because the three categories of schools exist and it was of interest to unravel the difference in impact of Free Secondary Education policy on access in the three categories of secondary schools so as to advise policy makers on where to spend more Free Secondary Education funds and get the desired results.

\section{Impact of Free Secondary Education Policy on Access to Secondary School Education in Small Schools}

To establish the impact of Free Secondary Education policy in small secondary schools, inferential statistics were used, that is Pearson product- moment correlation and regression analysis.

\begin{tabular}{llc}
\multicolumn{2}{l}{ Table 9: Relationship between Free Secondary Education funds and } \\
access in small schools
\end{tabular}

From Table 9, it can be observed that there was a positive and strong relationship between Free Secondary Education policy and access. The relationship was significant as signified by the calculated $p$-value of .000 which was less than the set $p-$ value of 0.05 . This means that an increase in Free Secondary Education funds would increase access.

To estimate the impact of Free Secondary Education funds, coefficient of determination was computed. The results were as shown in Table 10.

Table 10: Regression analysis of impact of Free Secondary Education funds on access in small secondary schools

\begin{tabular}{lcccc}
\hline Model & $\mathbf{R}$ & $\begin{array}{c}\mathbf{R} \\
\text { Square }\end{array}$ & $\begin{array}{c}\text { Adjusted } \mathbf{R} \\
\text { Square }\end{array}$ & Std. Error of the Estimate \\
\hline 1 & $.900^{\mathrm{a}}$ & .809 & .797 & 119.220 \\
\hline \multicolumn{4}{c}{ Predictors (constant) Free Secondary Education policy }
\end{tabular}

From Table 10, it can be noted that the contribution of the Free Secondary Education accounted for $80.9 \%$ of the variation on access as signified by the coefficient of .809 . The other $19.1 \%$ could be explained by other factors.

To determine whether Free Secondary Education was a significant predictor of access, ANOVA was computed. The results were as shown in Table 11. 
Table 11: Analysis of variance of Impact of Free Secondary Education on access in small secondary schools

\begin{tabular}{llrrrrr}
\hline Model & & Sum of Squares & Df & Mean Square & F & Sig. \\
\hline \multirow{2}{*}{1} & Regression & $905,217.335$ & 1 & 905217.335 & 63.687 & $.000^{\circ}$ \\
& Residual & $213,202.782$ & 15 & 14213.519 & & \\
& Total & $1,118,420.118$ & 16 & & \\
\hline \multicolumn{5}{c}{ a. Dependent Variable: Access } \\
& \multicolumn{5}{c}{ b. Predictors: (Constant), Free Secondary Education policy }
\end{tabular}

From Table 11, it can be observed that Free Secondary Education policy was a significant predictor of access as the calculated p-value was $.000<0.05$. This means that Free Secondary Education funds can be relied on as a predictor of access to secondary school education.

To determine the actual contribution, linear regression analysis was done. The results were as shown in Table 12.

Table 12: Regression Analysis of Impact of Free Secondary Education policy on Access in small secondary schools

\begin{tabular}{llccccc}
\hline Model & & \multicolumn{2}{c}{ Unstandardized Coefficients } & $\begin{array}{c}\text { Standardized } \\
\text { Coefficients } \\
\text { Beta }\end{array}$ & t & Sig. \\
& B & Std. Error & . & 17.427 & .000 \\
1 & Enrolment & 859.354 & 49.311 & & 7.980 & .000 \\
\hline & $\begin{array}{l}\text { Free Secondary } \\
\text { Education policy }\end{array}$ & 409.592 & 51.325 & .900 & 7.980 \\
\hline
\end{tabular}

Dependent Variable: Access. Regression equation $\mathrm{Y}=\mathrm{a}+\mathrm{bx}$

From Table 12, it can be revealed that one unit increase in Free Secondary Education funds can lead to increase in access by 409.592 units as indicated by the coefficient 409.592 . The regression equation is $Y=859.354+409.592$. This means that Free Secondary Education policy has a high impact on access to secondary school education.

Impact of Free Secondary Education policy on Access to Secondary School Education in Medium secondary schools

To establish the impact of Free Secondary Education Policy in medium secondary schools, inferential statistics were used, that is person product- moment correlation and regression analysis.

\begin{tabular}{lll}
\multicolumn{2}{c}{$\begin{array}{c}\text { Table 13: Relationship between Free Secondary Education funds } \\
\text { and access in medium secondary schools }\end{array}$} \\
\begin{tabular}{lll} 
& & Access \\
\hline \multirow{2}{*}{ Free Secondary } & Pearson Correlation & .984 \\
Education policy & Sig. (2-tailed) & .000 \\
& $\mathrm{~N}$ & 12 \\
\hline
\end{tabular}
\end{tabular}

From Table 13, it can be observed that there was a positive and strong relationship between Free Secondary Education policy and access. The relationship was significant as signified by the calculated $p$-value of .000 which was less than the set $p$ - value of 0.05 . The null hypothesis was therefore rejected. This means that an increase in Free Secondary Education funds would increase students' enrolment. To estimate the contribution of Free Secondary Education funds, coefficient of determination was computed. The results were as shown in Table 14. 
Table 14: Regression Analysis of the impact of Free Secondary Education policy on access in medium secondary schools

\begin{tabular}{llccc}
\hline Model & $\mathbf{R}$ & R Square & $\begin{array}{c}\text { Adjusted } \\
\text { R Square }\end{array}$ & $\begin{array}{c}\text { Std. Error of the } \\
\text { Estimate }\end{array}$ \\
\hline 1 & $.984^{\text {a }}$ & .968 & .965 & 41.192 \\
\hline \multicolumn{4}{l}{ a. Predictors: (Constant), Free Secondary Education policy }
\end{tabular}

From Table 14, it can be noted that the impact of Free Secondary Education accounted for $96.8 \%$ of the variation on access as signified by the coefficient of 0.968 . The other $3.2 \%$ could be explained by other factors. To determine whether Free Secondary Education was a significant predictor on students' enrolment, ANOVA was computed. The results were as shown in Table15.

Table 15: Analysis of Variance of impact of Free Secondary Education policy on access in medium secondary Schools

\begin{tabular}{llrrrrr}
\hline Model & & Sum of & Df & Mean Square & F & Sig. \\
& & Squares & & & & \\
\hline & Regression & $510,572.871$ & 1 & $510,572.871$ & 300.903 & $.000^{D}$ \\
& Residual & $16,968.046$ & 10 & $1,696.805$ & & \\
& Total & $527,540.917$ & 11 & & & \\
\hline
\end{tabular}

a. Dependent Variable: Access

b. Predictors: Free Secondary Education policy

From Table 15, it can be observed that Free Secondary Education policy was a significant predictor of access as the calculated p-value was $.000<0.05$. This means that Free Secondary Education funds can be relied on as a predictor of access to secondary school education.

To determine the actual contribution, linear regression analysis was done. The results were as shown in Table 16

Table 16: Linear Regression Analysis of the impact of Free Secondary Education policy on access in medium secondary schools

\begin{tabular}{|c|c|c|c|c|c|c|}
\hline \multirow[t]{2}{*}{ Model } & & \multicolumn{2}{|c|}{ Unstandardized Coefficients } & \multirow{2}{*}{$\begin{array}{l}\text { Standardized } \\
\text { Coefficients } \\
\text { Beta }\end{array}$} & \multirow[t]{2}{*}{$\mathrm{t}$} & \multirow[t]{2}{*}{ Sig. } \\
\hline & & B & Std. Error & & & \\
\hline \multirow[b]{2}{*}{1} & (Constant) & $1,040.141$ & 22.791 & & 45.637 & .000 \\
\hline & $\begin{array}{l}\text { Free Secondary } \\
\text { Education policy }\end{array}$ & 711.803 & 41.034 & .984 & 17.347 & .000 \\
\hline
\end{tabular}

a. Dependent Variable: Access in medium schools. Regression equation $\mathrm{Y}=\mathrm{a}+\mathrm{bx}$

From Table 16, it can be revealed that one unit increase in Free Secondary Education funds can lead to increase to access by 711.803units as indicated by the coefficient 711.803. The regression equation is $Y=1,040.141$ $+711.803 \mathrm{X}$. This means that Free Secondary Education policy has a high impact on access to secondary school education.

\section{Impact of Free Secondary Education Policy on Access to Secondary School Education in Large Secondary Schools}

To establish the impact of Free Secondary Education Policy in large secondary schools, inferential statistics were used, that is Pearson product- moment correlation and regression analysis. 
Table 17: Relationship between Free Secondary Education policy and access in large secondary schools

\begin{tabular}{llc}
\hline & & Access \\
\hline \multirow{2}{*}{ Free Secondary Education } & Pearson Correlation & .964 \\
policy & Sig. (2-tailed) & .008 \\
& $\mathrm{~N}$ & 5 \\
\hline
\end{tabular}

From Table 17, it can be observed that there was a positive and strong relationship between Free Secondary Education policy and access. The relationship was significant as signified by the calculated $p$-value of .008 which was less than the set $p-$ value of 0.05 . The null hypothesis was therefore rejected. This means that an increase in Free Secondary Education funds would increase students' enrolment.

To estimate the impact of Free Secondary Education funds, coefficient of determination was computed. The results were as shown in Table 18.

Table 18: Regression analysis for the influence of Free Secondary Education policy on access in large secondary schools

\begin{tabular}{lcccc}
\hline Model & $\mathbf{R}$ & $\begin{array}{c}\mathbf{R} \\
\text { Square }\end{array}$ & $\begin{array}{c}\text { Adjusted } \\
\text { R Square }\end{array}$ & $\begin{array}{c}\text { Std. Error of the } \\
\text { Estimate }\end{array}$ \\
1 & $.964^{\mathrm{a}}$ & .930 & .906 & 457.122 \\
\hline \multicolumn{5}{c}{ Predictors: Free Secondary Education policy }
\end{tabular}

From Table 18, it can be noted that the contribution of the Free Secondary Education accounted for $93 \%$ of the variation on access as signified by the coefficient of 0.930 . The other $7 \%$ could be explained by other factors.

To determine whether Free Secondary Education policy was a significant predictor on access, ANOVA was computed. The results were as shown in Table 19.

Table 19: Analysis of variance of impact of Free Secondary Education policy on access in

\begin{tabular}{|c|c|c|c|c|c|c|}
\hline \multirow[t]{2}{*}{ Model } & & $\begin{array}{l}\text { Sum of } \\
\text { Squares }\end{array}$ & Df & Mean Square & $\mathbf{F}$ & Sig. \\
\hline & Regression & $8,272,239.176$ & 1 & $8,272,239.176$ & 39.588 & $.008^{\mathrm{b}}$ \\
\hline 1 & Residual & $626,882.024$ & 3 & $208,960.675$ & & \\
\hline & Total & $8,899,121.200$ & 4 & & & \\
\hline
\end{tabular}

a. Dependent Variable: Access

b. Predictors: (Constant), high Free Secondary Education policy

From Table 19, it can be observed that Free Secondary Education policy was a significant predictor of access as the calculated $p$-value was $.000<0.05$. This means that Free Secondary Education funds can be relied on as a predictor of access to secondary school education.

To determine the actual impact, linear regression analysis was done. The results were as shown in Table 20. 
Table 20: Linear Regression Analysis of the impact of Free Secondary Education policy on access in large secondary schools

\begin{tabular}{|c|c|c|c|c|c|c|}
\hline \multirow[t]{2}{*}{ Model } & & \multicolumn{2}{|c|}{ Unstandardized Coefficients } & \multirow{2}{*}{$\begin{array}{c}\text { Standardized } \\
\text { Coefficients } \\
\text { Beta }\end{array}$} & \multirow[t]{2}{*}{$\mathrm{t}$} & \multirow[t]{2}{*}{ Sig. } \\
\hline & & B & Std. Error & & & \\
\hline \multirow[b]{2}{*}{1} & Constant & $-2,414.474$ & 910.252 & & -2.653 & .077 \\
\hline & $\begin{array}{l}\text { Free Secondary } \\
\text { Education policy }\end{array}$ & $3,700.167$ & 588.088 & 0.964 & 6.292 & .008 \\
\hline
\end{tabular}

a. Dependent variable: Access. Regression equation $\mathrm{Y}=\mathrm{a}+\mathrm{bx}$

From Table 20, it can be revealed that one unit increase in Free Secondary Education funds can lead to increase in access by $3,700.167$ units as indicated by the coefficient 3,700.167. The regression equation is $Y=-2,414.474$ $+3,700.167$. This means that Free Secondary Education Policy has a high impact on access to secondary school education.

\section{DISCUSSION}

The Kenyan government made a commitment to provide free basic education, which includes secondary education through the Sessional Paper No. 1 of 2005, to increase the transition to $70 \%$. ( Republic of Kenya, 2009). This was against the backdrop that one of the challenges that had faced the secondary school education sub-sector had been that of low transition from primary schools. This had been occasioned mostly by the fact that secondary school education was a fee paying sub-sector.

The first step in the implementation of Free Secondary Education policy started with a stakeholders' forum which led to the formation of the Task force on Affordable Secondary School Education. The key mandate of this team was to examine the cost as tabulated in secondary schools' joining instructions as well as identifying modalities for the implementation of Free Day Secondary Education. The guidelines were generated from the recommendations of the Taskforce as had been discussed and agreed by all the stakeholders in the sub-sector (Republic of Kenya, 2007). At that time, many schools were grossly under-enrolled, with several schools having fewer than 100 students in the entire school (Republic of Kenya, 2009). This phenomenon had serious implication on teacher utilization as most teachers would not be optimally utilized due to understaffing. The findings of this study confirmed this scenario, as most small schools had low enrollments (Table 3). The large schools on the other hand, were under-staffed and over-utilized. This phenomenon also affected enrolments as small schools were most likely to attract low enrolment while large schools would attract high enrolments. Furthermore, the staffing policy which is based on curriculum based establishment and enrollment. Schools with classes less than 40 students do not qualify for Teachers Service Commission teachers; the consequences as confirmed by this study are that most schools had as few as 3 to 6 Teachers Service Commission teachers.

The government subsidy to schools was based on capitation. That is, Free Secondary Education policy put in place funding of Ksh. 10,265.00 per child per year. The breakdown of the cost was as shown in Table 21:

Table 21

\begin{tabular}{lr}
\hline Vote head & Amount (Kshs) \\
\hline Tuition & $3,600.00$ \\
Repair, maintenance and improvement & 400.00 \\
Local travel and transport & 400.00 \\
Administration cost & 500.00 \\
Electricity, water and conservancy & 500.00 \\
Activity fees & 600.00 \\
Personal emoluments & $3,965.00$ \\
Medical & 300.00 \\
Total school fees & $10,265.00$ \\
\hline Source: Republic of Kenya (2009), Guidelines for Implementation of Free &
\end{tabular}


The parental obligations were stipulated as follows; boarding costs, lunch for day scholars and school levies approved by District Education Boards in consultation with Boards of Governors and Parents Teachers Associations. The recommendation for employment of non -teaching staff was as shown in Table 22:

Table 22

\begin{tabular}{cccc}
\hline Stream & Enrollment & $\begin{array}{c}\text { Day schools. } \\
\text { No. of workers }\end{array}$ & $\begin{array}{c}\text { Boarding schools. } \\
\text { No. of workers }\end{array}$ \\
\hline 1 & 180 & 6 & 10 \\
2 & 360 & 8 & 15 \\
3 & 540 & 9 & 20 \\
4 & 720 & 13 & 28 \\
5 & 900 & 15 & 30 \\
6 & 1080 & 18 & 36 \\
\hline \multicolumn{4}{r}{ Source: Republic of Kenya (2009), Guidelines for Implementation of Free } \\
\multicolumn{4}{r}{ Secondary Education }
\end{tabular}

This Free Secondary Education package was meant to make secondary school affordable and this would enable eligible students to transit from primary school to secondary schools with ease. The relationship between Free Primary Education funding and access was positive and strong for the four cohorts, 2008, 2009, 2010 and 2011. In this respect, Free Secondary Education funding accounted for $74.8 \%$ of the variation in access. This means that there was high demand for secondary school education and the high demand was motivated by the Free Secondary Education policy. In small secondary schools, enrolment ranged from 128 to 933, and the total enrolment in the 17 secondary schools was 8,452 for the 2008 to 2014 period. The total Free Secondary Education funding was $75,509,340.00$ Kenya shillings. The 12 medium secondary schools had a total enrolment of $16,058.00$ and the total Free Secondary Education funding was Ksh151, 655,110.00 while the 5 large secondary schools had a total enrolment of 15,261 and the total Free Secondary Education funding of Kshs. 146,060,685.00. These findings compare favourably with those of economic survey, 2015 (Republic of Kenya, 2015) at the National level. The economic survey, 2015 (Republic of Kenya, 2015) indicates that National transition rate trend from 2010 to 2014 was $68.9 \%, 69.4 \%, 68.4 \%, 76.8 \%$ and $80.4 \%$ respectively. The Economic survey, 2015 attributes the improvement from primary to secondary transition rate partly to the implementation of Free Secondary Education policy and expansion of physical facilities.

It is also important to note that for more or less the same period, nationally, enrolment rose (Republic of Kenya, 2015). From 2010 to 2014, enrolment in secondary schools was as shown in Table 23, as cited in Economic Survey 2015 (Republic of Kenya, 2015).

Table 23: Enrolment in Secondary Schools by Class and Sex, 2010 to 2014

\begin{tabular}{|c|c|c|c|c|c|c|c|c|c|c|}
\hline \multirow[t]{2}{*}{ Class } & \multicolumn{2}{|c|}{2010} & \multicolumn{2}{|c|}{2011} & \multicolumn{2}{|c|}{2012} & \multicolumn{2}{|c|}{2013} & \multicolumn{2}{|c|}{$2014^{\star}$} \\
\hline & Boys & Girls & Boys & Girls & Boys & Girls & Boys & Girls & Boys & Girls \\
\hline Form I & 266,707 & 232,226 & 276,965 & 244,636 & 282,555 & 249,573 & 327,775 & 289,753 & 339,134 & 328,017 \\
\hline $\begin{array}{l}\text { Form } \\
2\end{array}$ & 232,145 & 211,799 & 240,552 & 219,469 & 274,195 & 239,743 & 288,238 & 253,739 & 324,143 & 304,455 \\
\hline $\begin{array}{c}\text { Form } \\
3\end{array}$ & 216,786 & 181,823 & 224,637 & 188,408 & 239,149 & 218,278 & 267,221 & 228,869 & 291,440 & 261,088 \\
\hline $\begin{array}{c}\text { Form } \\
4\end{array}$ & 169,899 & 141,999 & 206,552 & 166,501 & 223,132 & 188,198 & 244,463 & 204,204 & 247,537 & 214,060 \\
\hline $\begin{array}{l}\text { Total } \\
\text { Grand } \\
\text { Total }\end{array}$ & $\begin{array}{r}885,537 \\
1,65\end{array}$ & $\begin{array}{l}767,847 \\
, 384\end{array}$ & $\begin{array}{r}948,706 \\
1,76\end{array}$ & $\begin{array}{l}819,014 \\
, 720\end{array}$ & $\begin{array}{r}1,019,031 \\
1,91\end{array}$ & $\begin{array}{l}895,792 \\
823\end{array}$ & $\begin{array}{r}1,127,697 \\
2,10\end{array}$ & $\begin{array}{l}976,565 \\
262\end{array}$ & $\begin{array}{r}1,202,254 \\
2,30\end{array}$ & $\begin{array}{l}1,107,620 \\
, 874\end{array}$ \\
\hline
\end{tabular}

Source: Ministry of Education Science and Technology

*Provisional

The total enrolment in both public and private secondary schools rose by $9.5 \%$ from 2.1 million in 2013 to 2.3 million in 2014. Total enrolment of girls increased by $10 \%$ from 1.0 million in 2013 to 1.1 million in 2014 . While that of boys grew by $6.6 \%$. The survival rate at secondary school level from form one to form four declined from $90 \%$ in 2013 to 
$88.4 \%$ in 2014. Survival Rate (SR) by grade is the percentage of a cohort of pupils (or students) enrolled in the first grade of a given level or cycle of education in a given school year who expected to reach successive grades. The purpose is to measure the retention capacity and internal efficiency of an education system. The retention rate for girls was lower at $87.5 \%$ compared to that of boys at $89.3 \%$ for the same cohort. In terms of Gross Enrolment Rate (GER) and Net Enrolment Rate (NER), figure 1 suffices.

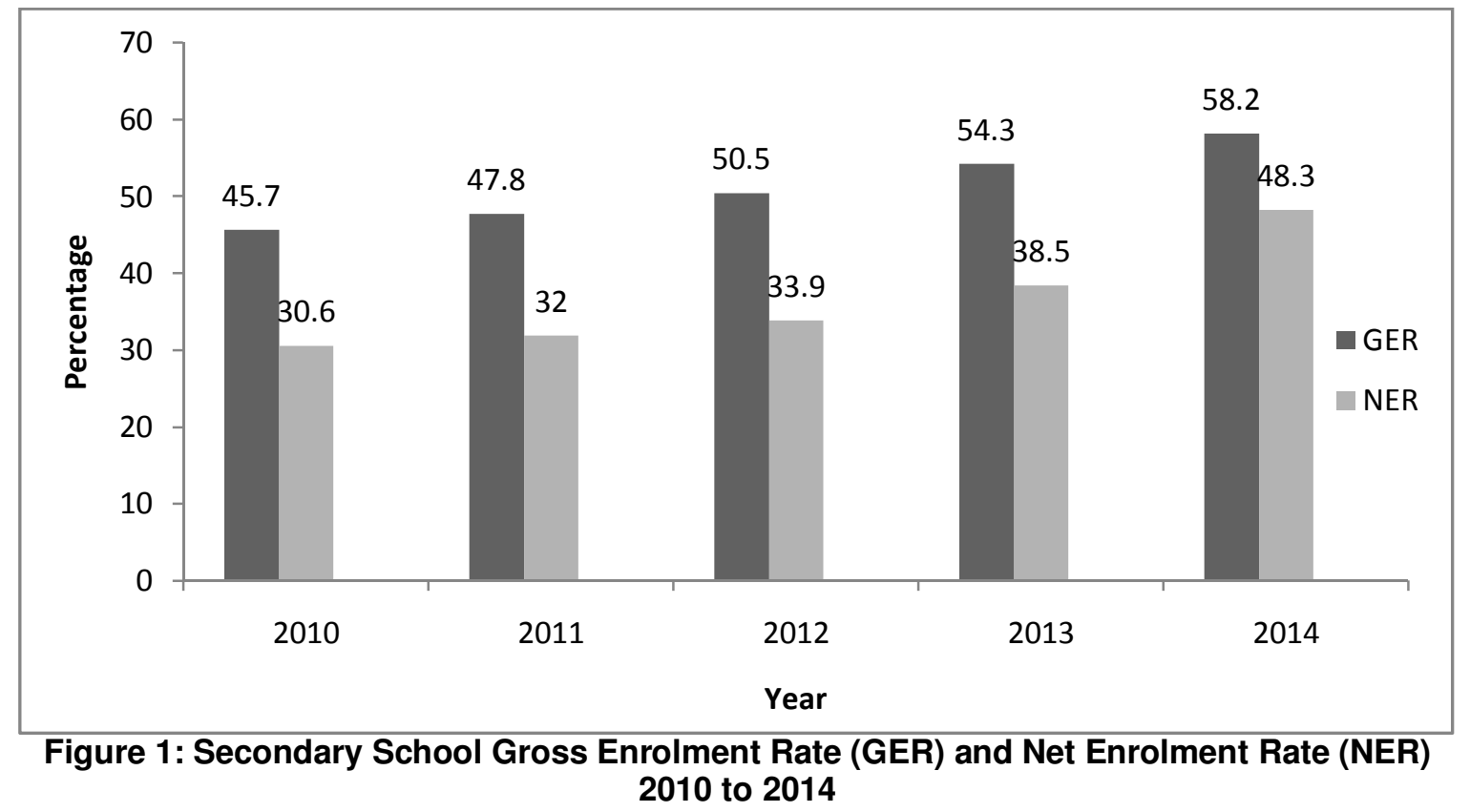

Figure 1 presents trend in secondary school GER and NER from 2010 to 2014 . The GER increased from $54.3 \%$ in 2013 to $58.2 \%$ in 2014. Significant improvement was also registered in the NER that increased from 38.5\% in 2013 to $48.3 \%$ in 2014 . The upward trend in NER can partly be attributed to the implementation of Free Day Secondary Education and infrastructural development in schools.

The findings of this study concur with that of Economic Survey 2015 (Republic of Kenya, 2015), but goes further to rigorously interrogate the impact of Free Secondary Education policy on access by determining the actual impacts on access in small secondary schools, medium secondary schools and large secondary schools. The impact of Free Secondary Education policy on access was very high in medium and large secondary schools, where Free Secondary Education policy accounted for $96.8 \%$ and $93 \%$ variations in access respectively. This means that Free Secondary Education funding produced desired results to a large extent in medium and large secondary schools. In small secondary schools, the impact was good but lower than that in medium and large secondary schools. Thus the impact in small secondary schools was .809 (Table 10). This means that Free Secondary Education policy accounted for $80.9 \%$ of variation in access.

\section{CONCLUSION}

Free Secondary Education policy has significantly impacted on access in secondary school education. The contribution is very high, particularly in medium and large secondary schools. This means that as envisioned by the Task force on affordable secondary school education and subsequent recommendations that were adopted, the cost of secondary school education was the major factor that negatively influenced access. Consequently, the subsidy has worked wonders for access to secondary school education sub-sector.

\section{RECOMMENDATIONS}

- Free Secondary Education funding should be increased so as to achieve the objectives of Free Secondary Education policy fully. 
- Small secondary schools should be merged, because the impact of Free Secondary Education funding is higher in medium and larger secondary schools as opposed to small secondary schools.

- The government should stop the registration of new secondary schools until when it is satisfied that the current secondary schools have met the optimal size threshold.

- Medium and large secondary schools based on prudent planning and logistics should be expanded to admit more students, because the impact of Free Secondary Education policy is higher in these schools.

- The government should continually evaluate the Free Secondary Education policy with a view of ensuring that the desired outcomes are being realized.

\section{REFERENCES}

Abagi, O. \& Oanda, O.I. (2014). Fifty years of Education Development in Kenya. Nairobi: Jomo Kenyatta Foundation.

Amunga, J.,Amadalo, M.M., \& Maiyo, J.K. (2010).The Influence of Schools' Performance Index on Enrolment in Kakamega South District Secondary Schools.Kenya Journal of Education Planning,Economics and Management. Vol (2): 76- 91.

Alex,A.A. (2004). A Report on Universal Primary education by African Network Compaign on education for all.GB: Oxfam.

Aroni, M.R. (2013). Effects of Subsidized Secondary Education on Access to Public Secondary Schools in Nyamache Division, Kisii County, KenyaUnpublished M.ED Research Project, Kenyatta University.

Bold, T., Kimenyi, M., Mwabu, G.X.,\&Sandefur, J. (2010).Does Abolishing Fees Reduce School.working paper WPS /2011-04.www.case.ox.uk.

Chabari, E.B. (2010).Challenges Facing Effective Implementation of Free Secondary Education in Public Secondary Schools in Kangundo District, Kenya. Unpublished Master's Thesis.Chuka University College.

Cohen, L., Manion, L. \&Marison, K. (2000). Research methods in education. London: Routledge Falemer.

Combs, D.H. (1968). World Educational Crisis: A Systems approach, New York: Oxford University Press.

Elifson, K.W., Runyon, R.P. \& Haber, A. (1990).Fundamental of Social Statistics.MC Graw Hill New york.

Glennerster, R., Kremer,M.,Mbiti I.,\&Takavarasha,K.(2011).Access and Quality in the Kenyan Education System. UnpublishedReport Prepared for Office of the Prime Minister of Kenya.

Gacheru J (2012). Factors Influencing Transition Rates from public primary schools to Secondary school level in Murang'a East District, Kenya. Department of Education Administration and Planning. Retrieved on $22^{\text {nd }}$ February 2014 from http://eap.uonbioac.ke/node/863.

Gogo, J.O. (2003). Impact of Cost Sharing Strategy on Access, Equity and Quality of Secondary Education: A Case Study of Rachuonyo District. Unpublished M.Ed thesis, Maseno University.

Gogo, J.,Ayodo, T.M.O., \&Othuon, L.A. (2010).The Impact of Cost Sharing Strategy on Access, Equity and Equality of Secondary Education in Kenya.Kenya J. Educational Planning, Economics Management.2(June, 2010).Journal of Educational Administration and Management.Vol 1(1): 001-006.

Gura, E.O (2015). The Effects of Kenya's Subsidized Secondary Education Program on Access, retention, equity and quality: A study of Nyakach Sub- County, Kisumu, Kenya.Unpublished M.ED Research Project, Kenyatta University.

Israel, Glenn, D. (2009). Determining Sample size.Program Evaluation and Organizational Development, Institute of Food and Agricultural Sciences, University of Florida, Gainesville 32611IFAS, University of Florida.PEOD-6. April, 2009.

Karagu, M.A., Oanda, O.I. \& Sifuna, D.N. (Eds). (2006). Themes in the study of the Foundations of Education.Nairobi:Jomo Kenyatta Foundation.

Keriga, L. (2009). Social Policy, Development and Governance in Kenya; An Evaluation and Profile of Education in Kenya,Nairobi: DPME.

Kerlinder, F.N. (1986). Foundations of behaviorial research. Fort Worth, TX: Holt, Rinehart, and Winston.

Kimitei, J.W. (2010). Determinants of Transition Rate to Secondary Education among Primary School Girls in Kenya: A Case of Keiyo District. Unpublished M.Phil Thesis. Moi University.

Leedy, P.D. \& Ormrod, J.E. (2005). Practical Research: Planning and design. New Jersey: Pearson Merrill Prentice Hall.

Lewin, K.M. (2008). Strategies for Sustainable Financing of Secondary Education in Sub-Saharan Africa. Washington D.C: World Bank.

Macharia, R. W. (2013). Impact of Free Secondary Education Policy on Internal Efficiency of Day Schools in Gatanga District, Murang'a County, Kenya.Unpublished Masters Project. Kenyatta University. 
Ministry of Education. (2012). Task force on the Re-Alignment of the Education Sector to the Constitution of Kenya 2010.Nairobi; Government printer.

Ministry of Education. (2009). Education Facts and Figures. EMIS; Ministry of Education, Kenya.

Ministry of Education. (2007). Report of the Task Force on Affordable Secondary Education. Nairobi: ShrendPub.LTD.

Ministry of Education. (2004). Education in Kenya: Challenges' and Policy Responses. Paper Prepared for the presentation at the Council on Foreign Relations Washington D.C.

Monk, D.H. (1992). "Education Productivity Research: An Update and Assessment of its Rolein Education Finance Reform." Educational Evaluation and Policy Analysis, Winter, 14(4): 307-332.

Mugenda, O.M., \& Mugenda, A.G.(2003). Research Methods: Quantitative and qualitative approaches, Nairobi: lab graphics services Itd publishers.

Munda, S.W. \& Odebero, S. (2014). The Influence of Education Costs on Students' Academic Performance in Kenya: An Empirical study of Bungoma County Secondary Schools. Asian Journal of Educational Research. Vol. $2(1): 2014$.

Munda, S.W., Tanui, E.K. \&Kaberia, L. (2010).Relationship between Selected Education Facilities and students' Academic Performance in Secondary Schools in Bungoma District, Kenya. EMSK Journal vol. 2 ISSN 2074- 5400 (pg. 97)

Mutula, K. (2013). Ministers speech during the release of 2012 KCSE results.

Ndolo, A.M., Simatwa, E.M.W. \& Ayodo, T.M.O. (2011). Effects of School Based Investments on access and financing of Secondary education in Homa-bay District, Kenya. Journal of Education. Educ. Res 2012 Vol. 2(12): $1821-1830$.

Ndolo, M.A. (2011). Effects of School Based Investments on Access and Financing of Secondary Education in Homa Bay District, Kenya. Unpublished M.ED Thesis, Maseno University.

Ngeno, C.V. \&Simatwa E.M.W. (2015). Influence of Free Policy on Gender Parity Index Repetition, Dropout, Wastage and Students Academic Achievement in Kericho County. Unpublished PhD Thesis, MAseno University.

Ngeno, C.V. \& Simatwa E.M.W. (2015). Influence of Free Secondary Education Policy on Dropout Rates in Kenya: A case Study of Kericho County. Greener Journal of Education Research. 2015 Vol. 5(4):152-175.

Ngeno, C.V., Simatwa, E.M.W. \&Ayodo, T.M.O. (2014). Impact of Free Secondary Education Policy on Gender Equity in Secondary Schools Education in Kenya: A Case study of Kericho County. Journal of Education Res. Vol. 5(3):83-97.

Ngware, M., Abuya, B., Admassu, K., \& Oketch, M. (2009). Quality and Access to Education in Urban Informal Settlement in Kenya.

Njoroge, D. (2011). Public School Enrolment on the Decline in Central. Education News December 2011: 22.

Nyaegah, O.J. (2011). Education and Millennium Development Goal Challenges Facing Management of FPE in Nyamira County-Kenya.Proceedings of the International Conference for EMSK.Held at University of Nairobi: EMSK.

Ohba, A. (2009). Does Free Secondary Education enable the poor to gain access, Create. Republic of Kenya.(2012a).Task Force on the Re-Alignment of the Education Sector to the Constitution of Kenya 2010.Nairobi;Government Printer.

Oketch, M. \& Somerset, A. (2010). Free Primary Education and after in Kenya: Enrolment Impact, Quality Effects and the Transition to secondary School. Create Pathways to Access Research monograph No. 37. Retrieved February $22^{\text {nd }}$ February, 2014 from http:www.create_rpc.org.

Osero, O.P., Nyakundi, M.R., Nyakundi, E. \&Nyakundi, N.E. (2013). Factors influencing performance of pupils on transition from lower primary to upper primary in Ekerenyo Division, Nyamira County, Kenya. proceedings of the fourth conference of EMSK 25-27 ${ }^{\text {th }}$ September, 2013 at Kabarak University.

Oso,W.Y. \&Onen, D. (2011). A general guide to writing research proposal and report: A handbook for beginning researchers, Nairobi: JKF publishers.

Psacharopoulous, G. \&Woodhall, M. (1985).Education for Development. New York: World Bank.

Republic of Kenya.(2015). Economic Survey 2015.Nairobi; Government printer.

Republic of Kenya. (2013). The Basic Education Act 2013. Nairobi; Government Printer.

Republic of Kenya.(2012). Ministry of Education Sessional Paper No. 14 of 2012, A Policy Framework for Education Training.

Republic of Kenya.(2010). 2009 Kenya Population and Housing Census.Nairobi; Government printer.

Republic of Kenya.(2010a).2009 Kenya Population and Housing Census. Nairobi; Government printer.

Republic of Kenya.(2012 b).Economic Survey 2012.Nairobi; Government printer.

Republic of Kenya.(2009). Guidelines for Implementation of Free Secondary Education, Nairobi: Ministry of Education. 
Republic of Kenya.(2007). Report of the Task force on Affordable Secondary Education. Nairobi: Ministry of Education.

Republic of Kenya.(2006).Strategic Plan 2006-2012; Nairobi; Government Printer.

Republic of Kenya. (2005).Sessional Paper No.1 of 2005 on A Policy Framework for Education, Training and Research.Nairobi: Government Printer.

Republic of Kenya.(1999). Totally Integrated Quality Education and Training.Report of the Commission of Inquiry into the Education System of Kenya.Nairobi: Government Printer.

Rono, K., Onderi, H. \& Awino, J. (2013).Perceptions of Causes of Poor Academic Performance amongst Selected Secondary Schools in Kericho Sub County. Implications for School Management. Proceedings of the Fourth Conference of EMSK $25^{\text {th }}-27^{\text {th }}$ September 2013 at Kabarak University.

Saitoti, G. (2004). Education in Kenya: Challenges and Policy responses. Paper prepared for presentation at the Council on Foreign Relations. Washington DC.

Sifuna, D.N. (1990).Development of Education in Africa; the Kenyan experience, Nairobi: Initiative.

Sifuna, D.N. \&Oanda, O.I. (2014). Historical and Contemporary Trends in the Development of Education in Kenya. Nairobi. Jomo Kenyatta Foundation.

Simon \& Goes (2013):http://www.dissertationrecipes.com/wpcontent/uploads/2011/04/ex-Post-Fact research.pdf(accessed on $11^{\text {th }}$ Jan 2015).

Todaro, P.M. (1994). Economics of a Developing World. London: Longman publication.

UNESCO. (2011).Global Education Digest 2011: Comparing Education Statistics Across the World. Montreal, Canada; UNESCO.Retrieved on $22^{\text {nd }}$ February 2014 from http/www.uis.unesco.org.

UNESCO. (2008). Regional Overview: Sub Saharan Africa. UNESCO.

UNESCO.(1990). Report of the World Conference on Education for All.Jomtiem, Thailand; UNESCO.

UNICEF. (2011). UNICEF: Gender Equality in Secondary Education. Retrieved on $22^{\text {nd }}$ February 2014 from http://www.unicef.org/educationindex.

Veriava,F. (2002).Eradicating Barriers to Education: An introduction to the Education Rights Project; SA epublication, Vol. 3(2):13-15.

Verspoor, A. (2008). At the Crossroads; Choices for Secondary Education in Sub-Saharan Africa; Washington ,D.C: World Bank

Wango, G. (2009).School Administration and Management: Quality Assurance and Standards in Schools. Nairobi; Jomo Kenyatta Foundation.

Wanja, H.W. (2014). An understanding of the Trends in the Free Secondary Education funding policy and transition rates from primary to secondary education in Kenya. Journal of Education and Social Research.Vol. 4 No. (1): 133-142.

Yamane, T. (1967).Statistics, An Introductory Analysis, New York: Harper and Row.

Cite this Article: Ndolo MA, Simatwa EMW and Ayodo TMO (2016). Impact of Free Secondary Education Policy on Access to Secondary School Education in Kenya. A Case Study of Mbita and Suba Sub-Counties. Greener Journal of Educational Research, 6(2): 067-085, http://doi.org/10.15580/GJER.2016.2.032816070 